\title{
CAN SOCIAL MEDIA PROMOTE SOCIAL PRESENCE AND ATTITUDE IN EFL CLASSES?
}

\author{
Dr. Sibel Ergun ELVERICI \\ ORCID:0000-0002-6921-5013 \\ School of Foreign Languages \\ Yildiz Technical University \\ Istanbul, TURKEY
}

Received: 20/01/2020 Accepted: 20/05/2020

\begin{abstract}
It is true that social media has a significant presence in today's world and has become an integral part of our lives. Researchers have been trying to find ways to integrate social media to language classes to take advantage of the possibilities social media can offer such as fostering students' engagement with the language, increasing their motivation and making them socially and collaboratively connected. The underlying idea behind this is to take advantage of the possibilities social media can offer to achieve a better learning environment resulting with more effective learning outcomes. Thus, this study seeks to understand and reveal the effects of integrating social media on students' social presence and their attitudes to it when social media is integrated in foreign language classes. Facebook was used as part of high school students' curriculum in English lessons. Explanatory mixed design was used. Data were analysed by using paired samples t-test and content analysis. The results of the study showed that there was no significant difference in students' attitude to social media but there was a significant difference in their social presence.
\end{abstract}

Keywords: Social media, social presence, Facebook, EFL classes, technology integration.

\section{INTRODUCTION}

Rapid developments in technology and communication have made the communication through the internet essential part of people's lives in today's world. There is no doubt that the internet provides the fastest and easiest way to achieve information. Millions of people and therefore groups which are constantly growing and developing are connected to each other through the internet. Since more and more people have access to the internet, more and more people have started use the social media. In this respect, social media is considered to be one of the best ways of communication and has been referred to with different names and affecting socialisation. Social media's growing attraction for the educators and researchers to investigate its contributions to education is attributed to its enabling communication and having millions of users. When considering people's using social media to stay in touch, get social support, get information based on cooperation and share it, create content and form it by bringing it together, social media sites can be considered as pedagogical tools as well and they have the potential to support teaching and learning activities (Leong, Ibrahim, Dalvi-Esfahani, Shahbazi \& Nilashi, 2018; Chen, 2018; Nagel, Remillard, Aucoin, \& Takenish, 2018) which should not be underestimated in especially EFL classes to explore and meet the diverse learning needs of students. Yet, social media research can still be considered to be relatively new but is definitely developing and some suggest the need for a solid framework for social media in particular using Facebook in education (Manca \& Ranieri, 2016; Zhang, \& Gupta, 2018). Consequently, Facebook is taken as the social media tool in this study which is still the most popular social media tool and enables fast and efficient communication (Facebook, 2019). Yet, the primary focus of Facebook is believed to provide social interaction which is also in line with social presence as part of the main focus of this study. 


\section{LITERATURE REVIEW}

Since the terms web 2.0, social media and social networking sites are usually used interchangeably (Greenhow \& Lewin, 2016; Peeters, 2018) why the term 'social media' is used in this study is explained to get a better look at this issue. When the literature is considered, it is seen that web 2.0 is usually considered to be a technical term and referred to as the common name of the places where information is generated and developed by their users first and then easily shared (Chugh \& Ruhi ,2017; Greenhow \& Askari, 2017). The improvements of web 2.0 paved way to the changes in the internet applications and they have been given different names such as social networks, social sites and online communities. One of the definitions of the term 'social media' is "applications, services, and systems that allow users to create, remix, and share content" Junco (2014, p.6). While enabling connectivity, communication and collaboration social media appears in different forms such as blogs, vlogs and instant messaging (Zincir, 2017; Chugh \& Joshi 2017). The majority of social media sites help individuals who have common features like interests, needs and political ideas to have a contact and communicate with each other. People use social sites for various purposes such as making new friends, staying in touch, communicating with people with similar interests, organizing social events or joining them, sharing pictures and playing games. Apart from this socialization feature, social media sites help users to restructure their learning in an open-ended social context. They do this by going beyond the access of content which means their restructuring information in an ongoing process while giving opportunities that would allow social application of this information. Social media sites are informal places that play an important role in the continuation of interaction outside class whose users are usually young people. They are expected to increase group interactions and co-operations while connecting users in web-mediated environment with a great deal of information exchange. Using social media for educational purposes has been a matter of interest for a long time on the part of the researchers, one of which was about Facebook dating back to 2006 (Hewitt \& Forte, 2006). Social media as part of technology integration for educational purposes has surely involves challenges and since then there have been disappointing findings about social media use, especially Facebook as well (Madge, Meek, Wellens \& Hooley, 2009; Wood, 2014). However, today social media is widely used in educational settings and social media is believed to support school related tasks and improve student's performance (Greenhow \& Robelia, 2009; Anankulladetch, 2017).Social media’s enabling socializing easily and becoming an inevitable fact of our lives led to its increasing use and research in education (Huang, Wu, She \& Lin, 2014; Ma, 2017; Akbari, Naderi, Simons \& Pilot, 2016). This may be because social media provides students a place where they can interact about their studies. They also have the opportunity of participating in collaborative settings outside of school and it can help students to direct their interest to academic subjects (Lau, Lui, \& Chu, 2016; Lantz-Andersson, 2018). Social media differs from learning management systems in that learning management systems students already use do not allow any place for social communication tools and their personal profiles. However, students require more and more autonomy, interaction and social communication opportunities and the literature regarding this subject indicates that social media tools support activities used in education in terms of interaction, cooperation, information and resource sharing, communication and critical thinking (Ha, Joa, Gabay \& Kim, 2018; Sheeran \& Cummings, 2018). It can be argued that social media has the potential like improving students', teachers' and parents' communication skills as well as other community member's while allowing to form online professional learning communities (Cox \& McLeod, 2014; Nalbone et.al., 2016). In this respect, as well as offering a wide range of topics in terms of entertainment, being a social media tool, it can be suggested that Facebook also keeps the potential for learning and gathering information from different fields and promotes collaborative learning (Menzies, Petrie \& Zarb, 2017). This can be considered as a suggestion that Facebook can be used as a complementary tool (Hong \& Gardner, 2019). This is also supported in other research which suggest that Facebook enables users to discuss on a subject that they are interested in by giving them an endless space and sharing opportunity which ultimately results in supporting students in their learning and can be used for educational activities (Luke, 2019; Ware, Kern, \& Warschauer, 2016). Involving social media tools in education is considered to be a valuable and significant asset for socializing and supporting collaboration in the lives of young people. This aspect can be linked to social presence and although they were designed for other purposes it can be said that social media sites have started to appear to a great extent in young people's education life. 
How is social presence connected to social media then? Among many other reasons, the importance of social presence also comes from its influence in learning. Social presence is believed to help participants form relationships based on mutual trust suggesting a positive effect on learning (Lin, Kang, Liu, \& Lin, 2016; Sung \& Mayer, 2012), for students the absence of which may lead to a high level of frustration, an unreasonably critical attitude toward the professor's efficacy as well as a low level of affective learning (Wei, Chen, and Kinshuk, 2012). The definitions of social presence are continuous at least for the researchers investigating this term. In this continuity researchers tend to conceptualize social presence as the degree of an individual's being "real" and "there". These definitions have usually focused on the degree of an individual's ability to reflect themselves as real and be real in online environments. Social presence was developed by Short, Williams and Christie in 1976 and one of the definitions of Williams (1978a) described social presence as the feeling of communicating. These researchers defined social presence as the degree of being there when two people are communicating through a communication tool which can also be interpreted as the quality of being there. Yet, contextual and individual factors as well as the individual features of participants play an important role in perceiving the degree of social presence (Kang and Gratch, 2014; Oh, Bailenson \& Welch, 2018). In that matter, being the most popular social media tool and a large component of the global world, Facebook is believed to naturally support social presence (Rap \& Blonder, 2016; Gordon, 2016). Its providing different areas for both teachers and students for communication makes social media more embedded in our lives and is expected to support successful learning and social presence.

Given the growing role of emerging technologies in education, it is important for educators to understand the role of social media in the foreign language classroom and of course using social media for educational purposes is not free from limitations. Some of the concerns attributed to using technology in educational settings are inactive behaviour, lack of academic language use, teacher interest/training, teacher workload and privacy concerns (Aydin, 2014; Bahati, 2015; Godwin-Jones, 2019). However, as aforementioned, since the emerging technologies in education is growing day by day, their integration to the language classroom needs to be taken into consideration more especially regarding different skills by the educators and this idea finds itself a large place in the related literature (Zheng, Yim \& Warschauer, 2018; Chugh \& Ruhi, 2018; Cetinkaya \& Sutcu, 2019). While providing young people with both interesting and encouraging tools, social media can create fun and interactive content and allow young people to reach effective and comfortable learning process (Imlavi \& Gregg, 2014 Kawachi, 2019). Social media’s supporting collaborative learning and critical thinking, by allowing their members to work in personalized environments, can be a way to improve its members' skills such as communication and writing (Dizon, 2016; Suswati \& Saleh, 2019; Chandran, Plaindaren, Pavadai \& Yunus, 2019).

\section{THE IMPORTANCE AND PURPOSE OF RESEARCH}

It can be argued that today's students are more apprehensive and technologically knowledgeable than in the past and due to growing advances in technology constant change in many aspects of life is inevitable. Since social media sites include many people as readers and at the same time writers and appear with their socialization features like personalized content, information sharing and cooperation, it brings with itself the necessity to investigate the role of social media in education. Therefore, as mentioned before, this study takes Facebook, as being the most popular and known social media tool, and investigates its effects in relation to students' social presence and students' attitudes in in the context of learning a foreign language, English.

The hypotheses that have been formed in line with the aims of the study is:

1. In foreign language lessons where social media is used, the social presence levels of students are higher compared to the ones whose foreign language lessons do not use social media.

2. In foreign language lessons where social media is used, the attitude of students to social media is higher compared to the ones whose foreign language lessons do not use social media.

As for the qualitative part the question is:

What are the opinions of students about the effects of the use of social media in foreign language lessons on their attitude to social media? 


\section{THE STUDY}

The study aimed to find whether using social media affects students' social presence as well as their attitude to social media in foreign language teaching, in this study English by using mixed method model.

\section{Study Group}

The study group was comprised of a 32 high school students who attended a private school in different campuses in Istanbul. The students were in their second year at high school and followed the same curriculum. Experimental group had 8 boys and 8 girls and the control group had 9 boys and 7 girls. The quantitative part of the study was conducted according to the principles of quasi-experimental design since the classes were already formed. The teacher of the experimental group had 16 years of teaching experience and was working in the school the study was conducted for 10 years. The teacher of the control group had 19 years of teaching experience and was working in the school the study was conducted for 12 years.

\section{Data Collection Tools}

In compliance with the set goal of this study, explanatory mixed pattern was used. Quantitative data were collected before the qualitative data. For the quantitative part of the study, to measure students' perceptions of social presence and to be as comprehensive as possible 5-point Likert social presence scale was used (Arbaugh,et al., 2008). As for their attitude to social media, social media attitude scale developed for teenagers was used (Otrar \& Argin, 2015). Although the social presence scale was translated into Turkish and its validity and reliability was worked on, considering the ages of the students, the scale was translated into Turkish again and its validity and reliability was re- evaluated by different professionals both in English and in Turkish. A pilot study was also carried out with 49 students from 8th grades in a different school. Cronbach's Alpha was found to be 0.96 and KR-20 was found to be 0.86 . Social media attitude scale (Otrar $\&$ Argin, 2015) consisting of 23 items and its Cronbach's Alpha was .85. Semi-structured interview was used for the qualitative part of the study. The interview was conducted with 7 boys and 6 girls who volunteered to take part in the interview. Since the students answered the questions in great detail in the surveys, in the interview they were not asked to answer questions like how much time they spend on the social media or for what purposes they use it unless part of the sub-questions in line with the nature of the semi-structured interview. Instead, the questions asked in the interview aimed to find out the students' reflections on the use of social media both in their private lives and as part of the English lessons and encouraged them to comment on it. Some of the questions asked are "How did you feel when you shared your views on the topics?" and "Do you find it worth using Facebook in the English lessons? Why/Why not?" The interviews were recorded and later transcribed in accordance with the procedures of content analysis.

\section{Implementation}

Before the implementation started the students were given brief information about the study. They were then given the social presence scale and the social media attitude scale and asked to fill in. The same process was applied at the end of the implementation. The implementation process was carried on for 7 weeks. In addition to their technology supported foreign language education the students in the experimental group used social media for their foreign language lessons, English, while the control group on another campus of the same school continued their usual technology supported foreign language education. First the students were asked to join the Facebook page created by the researcher. They were then asked to actively share their ideas in the discussions which were prepared according to the topics of their English lessons stated in the curriculum. During the course of the experiment, the students were motivated and encouraged by their teacher. The discussion questions which were aligned with their weekly syllabus were given at the end of every week. Some of the questions presented at the page were "What is the best way of shopping? Do you prefer online shopping? Why/Why not? How would you describe digital era?" The researcher regularly observed the lessons and met the students in person. 


\section{Data Analysis}

For the quantitative part of the study, in order to find out the difference between the experimental and control groups in terms of their social presence and their attitudes to social media, t- test was used.

For the qualitative part of the study, content analysis which included coding, categorization, description and interpretation was used (Patton, 2002). In the coding stage, students' responses to interview questions were examined and meaningful parts were determined from which codes were formed and then put into categories during which data were divided into different meaningful sections and these sections were given different names. The students' real names were not used and given codes. $\mathrm{K}$ for girls, and $\mathrm{E}$ for boys was used, which are the first letters of sexes in Turkish. Then the data were coded in a general framework. In order to ensure reliability and to eliminate any wrongdoings resulting from the researcher, the support of another researcher in the field were referred to. The data gained from the interview were first coded and after waiting for a week recoded, checked and compared by both researchers for the reasons of ensuring reliability. Next, main ideas were summarized and listed in the description stage and final conclusions were drawn in the interpretation stage. The researcher and the other researcher met and discussed their ideas regularly during the whole process aiming to reach a consensus on emerging themes, the inter-rater reliability of which was found to be, 87 . There were two themes that would explain the ideas appeared in the interviews in general. In the last section, both codes and themes were put into tables.

\section{FINDINGS}

Findings Regarding Homogeneity for Social Presence

Table 1. Experimental Group's Homogenity for Social Presence

\begin{tabular}{lccc}
\hline \multirow{2}{*}{ Values } & & \multicolumn{2}{c}{ Social Presence } \\
\cline { 3 - 4 } & & Pre-test & Post-test \\
\hline $\mathrm{N}$ & $\bar{x}$ & 16 & 16 \\
Normal & ss & 25.31 & 38.25 \\
Par. & & 5.12 & 1.80 \\
$\mathrm{Z}$ & & .972 & .935 \\
$\mathrm{P}$ & & .870 & .293 \\
\hline
\end{tabular}

To find out whether the data were distributed homogenically Shapiro-Wilk test was applied and the results of the experimental group for social presence pre- test $(\mathrm{z}=.972 ; \mathrm{p}>.05)$; post- test $(\mathrm{z}=.935 ; \mathrm{p}>.05)$ showed that data were distributed normally.

Table 2. Control Group's Homogenity for Social Presence

\begin{tabular}{|c|c|c|c|}
\hline \multirow{2}{*}{ Values } & & \multicolumn{2}{|c|}{ Social Presence } \\
\hline & & Pre-test & Post-test \\
\hline $\mathrm{N}$ & & 16 & 16 \\
\hline Normal & $\bar{x}$ & 23.13 & 25.38 \\
\hline Par. & ss & 1.31 & 5.85 \\
\hline$z$ & & .932 & .958 \\
\hline $\mathrm{p}$ & & .259 & .634 \\
\hline
\end{tabular}

To find out whether the data were distributed homogenically Shapiro-Wilk test was applied and the results of the control group for social presence pre- test $(\mathrm{z}=.932 ; \mathrm{p}>.05)$; post- test $(\mathrm{z}=.958 ; \mathrm{p}>.05)$ showed that data were distributed normally. 
Table 3. Experimental Group's Homogenity for Social Media Attitude Scale

\begin{tabular}{lccc}
\hline \multirow{2}{*}{ Values } & \multicolumn{3}{c}{ Social Media Attitude Scale } \\
\cline { 3 - 4 } $\mathrm{N}$ & & Pre-test & Post-test \\
\hline Normal & $\bar{x}$ & 16 & 16 \\
Par. & ss & 56.75 & 57.06 \\
$\mathrm{z}$ & & 3.53 & 3.60 \\
$\mathrm{p}$ & & .977 & .951 \\
\hline
\end{tabular}

To find out whether the data were distributed homogenically for the experimental group Shapiro-Wilk test was applied and the results for social presence pre- test $(\mathrm{z}=.977 ; \mathrm{p}>.05)$; post- test $(\mathrm{z}=.951 ; \mathrm{p}>.05)$ showed that data were distributed normally.

Table 4. Control group social media attitude scale Shapiro-Wilk test results

\begin{tabular}{lccc}
\hline \multirow{2}{*}{ Values } & & \multicolumn{2}{c}{ Social Media Attitude } \\
\cline { 3 - 4 } $\mathrm{N}$ & & Pre-test & Post-test \\
\hline Normal & $\bar{x}$ & 16 & 16 \\
Par. & ss & 61 & 53.46 \\
$\mathrm{z}$ & & 11.01 & 10.63 \\
$\mathrm{p}$ & & .982 & .920 \\
\hline
\end{tabular}

To find out whether the data were distributed homogenically for the experimental group Shapiro-Wilk test was applied and the results for social presence pre-test $(\mathrm{z}=.982 ; \mathrm{p}>.05)$; post-test $(\mathrm{z}=.920 ; \mathrm{p}>.05)$ showed that data were distributed normally.

Table 5. Comparison of Pre-tests

\begin{tabular}{cccccccccc}
\hline \multirow{2}{*}{ Point } & Groups & $N$ & $\overline{\mathrm{x}}$ & $S S$ & $\mathrm{Sh}_{\overline{\mathrm{x}}}$ & \multicolumn{3}{c}{$t_{\text {Test }}$} \\
& & & & & & $\boldsymbol{t}$ & $S d$ & $p$ \\
\hline $\begin{array}{c}\text { Social Presence } \\
\text { Pre tests }\end{array}$ & Exper. & 16 & 25.31 & 5.12 & 1.28 & & & \\
\hline
\end{tabular}

To find out whether there was a significant difference between the pre-tests of experimental and control groups for social presence scale, independent samples $t$-test was applied. The results with $(t=1.655 ; \mathrm{p}<.05)$ showed that there was not a significant difference.

Table 6. Comparison of pre-tests of social media attitude scale for experimental and control groups

\begin{tabular}{cccccccccc}
\hline \multirow{2}{*}{ Puan } & Groups & $N$ & $\overline{\mathrm{x}}$ & SS & $\mathrm{Sh}_{\overline{\mathrm{x}}}$ & \multicolumn{4}{c}{$t_{\text {Test }}$} \\
& & & & & & & \multicolumn{1}{c}{$S d$} & $p$ \\
\hline \multirow{2}{*}{ SMTO Pre test } & Exper & 16 & 56.75 & 3.53 & .883 & & \\
& Control & 16 & 61 & 3.89 & .974 & -1.470 & 121 & .152 \\
\hline
\end{tabular}


To find out whether there was a significant difference between the pre-tests of experimental and control groups for social media attitude scale, independent samples $t$-test was applied. The results with $(t=-1.470 ; p$ $<.05)$ showed that there was not a significant difference.

\section{Comparison of Social Presence Scale Results for Pre and Post-Tests For Experimental and Control Groups}

Table 7. Comparison of experimental group's pre and post-tests

\begin{tabular}{|c|c|c|c|c|c|c|c|c|}
\hline \multirow{2}{*}{ Points } & \multirow{2}{*}{ Groups } & \multirow{2}{*}{$N$} & \multirow{2}{*}{$\overline{\mathrm{x}}$} & \multirow{2}{*}{ sS } & \multirow{2}{*}{$\mathrm{Sh}_{\overline{\mathrm{x}}}$} & \multicolumn{3}{|c|}{$t_{\text {Test }}$} \\
\hline & & & & & & $t$ & $S d$ & $p$ \\
\hline Social Presence & Pre-test & 16 & 25.31 & 5.12 & 1.28 & & & \\
\hline Pre- test Post- test & Post-test & 16 & 38.25 & 1.80 & 4.52 & -9.295 & 5.56 & ,000 \\
\hline
\end{tabular}

To find out whether there was a significant difference between experimental group's pre-test and post-test results paired samples t-test was applied. The results for arithmetic mean for social presence were found to be significant with $(\mathrm{t}=-9.295 ; \mathrm{p}<.05)$ This difference was for post-tests which meant after the treatment the experimental group's social presence level increased significantly.

Table 8. Comparison of control group's pre and post-test points

\begin{tabular}{|c|c|c|c|c|c|c|c|c|}
\hline \multirow{2}{*}{ Points } & \multirow{2}{*}{ Groups } & \multirow{2}{*}{$N$} & \multirow{2}{*}{$\overline{\mathrm{x}}$} & \multirow{2}{*}{$S S$} & \multirow{2}{*}{$\mathrm{Sh}_{\overline{\mathrm{x}}}$} & \multicolumn{3}{|c|}{$t^{t}$ Test } \\
\hline & & & & & & $t$ & $S d$ & $p$ \\
\hline Social Presence & Pre-test & 16 & 23.13 & 1.31 & .328 & \multirow{2}{*}{-1.434} & \multirow{2}{*}{6.27} & \multirow{2}{*}{.172 } \\
\hline Pre test- Post test & Post-test & 16 & 25.38 & 5.85 & 1.46 & & & \\
\hline
\end{tabular}

To find out whether there was a significant difference between control group's pre-test and post-test results paired samples t-test was applied. The results for arithmetic mean for social presence were not found to be significant with $(\mathrm{t}=-1.434 ; \mathrm{p}<.05)$.

Table 9. Comparison of Experimental group’s SMTO Pre-test-Post-test Points

\begin{tabular}{cccccccccc}
\hline \multirow{2}{*}{ Points } & Groups & $N$ & $\overline{\mathrm{x}}$ & SS & $\mathrm{Sh}_{\overline{\mathrm{x}}}$ & \multicolumn{3}{c}{$t_{\text {Testi }}$} \\
& & & & & & $\boldsymbol{t}$ & $S d$ & $p$ \\
\hline SMTO Pre-test & Pre-test & 16 & 56.75 & 3.531 & .883 & & -1.232 & 1.014 & .237 \\
Post-test & Post-test & 16 & 57.06 & 3.605 & .901 & & & \\
\hline
\end{tabular}

To compare experimental group's s social media attitude points and find out whether there was a significant difference, paired samples $\mathrm{t}$-test was applied. the results with $(\mathrm{t}=-1.232 ; \mathrm{p}<.05)$ showed that there was not a significant difference. 
Table 10. Comparison of Control Group's SMTO Pretest-Postest Points

\begin{tabular}{|c|c|c|c|c|c|c|c|c|}
\hline \multirow{2}{*}{ Points } & \multirow{2}{*}{ Groups } & \multirow{2}{*}{$N$} & \multirow{2}{*}{$\bar{x}$} & \multirow{2}{*}{$S S$} & \multirow{2}{*}{$\mathrm{Sh}_{\overline{\mathrm{x}}}$} & \multicolumn{3}{|c|}{$t_{\text {Test }}$} \\
\hline & & & & & & $t$ & $S d$ & $p$ \\
\hline \multirow{2}{*}{ SMTO Pre-test Post-test } & Pre-test & 16 & 61 & 11.01 & 2.754 & \multirow{2}{*}{.473} & \multirow{2}{*}{15.84} & \multirow{2}{*}{.643} \\
\hline & Post-test & 16 & 59.13 & 10.63 & 2.660 & & & \\
\hline
\end{tabular}

To compare control group's social media attitude scale points for pre-tests and post-tests paired samples $\mathrm{t}$ test was applied. The results with $(\mathrm{t}=.473 ; \mathrm{p}<05)$ showed that the difference was not significant. Control group's points did not increase significantly.

Table 11. Comparison of Experimental and Control Groups' post-tests for social presence

\begin{tabular}{|c|c|c|c|c|c|c|c|c|}
\hline \multirow[b]{2}{*}{ Points } & \multirow{2}{*}{ Groups } & \multirow{2}{*}{$N$} & \multirow{2}{*}{$\bar{X}$} & \multirow{2}{*}{$S S$} & \multirow{2}{*}{$\mathrm{Sh}_{\overline{\mathrm{x}}}$} & \multicolumn{3}{|c|}{$t_{\text {Test }}$} \\
\hline & & & & & & $t$ & $S d$ & $p$ \\
\hline Social Presence & Exper. & 16 & 38.25 & 1.80 & .45 & \multirow{2}{*}{8.408} & \multirow{2}{*}{1.53} & \multirow{2}{*}{,000 } \\
\hline Post test & Control & 16 & 25.38 & 5.85 & 1.46 & & & \\
\hline
\end{tabular}

To compare experimental and control groups' social media attitude scale points for post-tests independent samples $\mathrm{t}$ test was applied. The results with $(\mathrm{t}=8.408 ; \mathrm{p}<05)$ showed that the difference was for the experimental group and significant.

Table 12. Comparison of Experimental and Control Groups' post tests for social media attitude scale points

\begin{tabular}{|c|c|c|c|c|c|c|c|c|}
\hline \multirow{2}{*}{ Points } & \multirow{2}{*}{ Groups } & \multirow{2}{*}{$N$} & \multirow{2}{*}{$\overline{\mathrm{X}}$} & \multirow{2}{*}{$S S$} & \multirow{2}{*}{$\mathrm{Sh}_{\overline{\mathrm{x}}}$} & \multicolumn{3}{|c|}{$t_{\text {Test }}$} \\
\hline & & & & & & $t$ & $S d$ & $p$ \\
\hline \multirow{2}{*}{ SMTO Post test } & Exper. & 16 & 57.06 & 3.60 & .901 & \multirow{2}{*}{,- 734} & \multirow{2}{*}{2.808} & \multirow{2}{*}{.468} \\
\hline & Control & 16 & 59.13 & 10.63 & 2.66 & & & \\
\hline
\end{tabular}

To compare experimental and control groups' social media attitude scale points for post-tests independent samples $\mathrm{t}$ test was applied. The results with $(\mathrm{t}=-, 734 ; \mathrm{p}<05)$ showed that the difference was not for the experimental group and not significant.

\section{Drawing on the Data from the Students' Interviews}

To find out students' opinions about the effects of the use of social media in foreign language lessons in the qualitative part of the study, semi-structured interviews were conducted. After the implementation of social media supported lessons for 7 weeks with the experimental group, 13 students were volunteered to take part in the interview. Data gathered from the interview were brought together in codes first and themes that would cover these codes were formed. The opinions of students about the impact of using social media in foreign language classrooms on students' social presence were examined in detail and the themes which were found by using content analysis were as follows: communication and fun. Only some of the students' own expressions are given place here due to the richness of data as well as the space limitations. The tables showing students' responses and both the codes and themes are given below. 
Table 13. Some of the students' responses that led way to the theme "communication"

\begin{tabular}{cl}
\hline Student & \multicolumn{1}{c}{ Response } \\
\hline K5 & $\begin{array}{l}\text { "I go on Facebook almost every day and so do my friends and I think it sort of helped us know } \\
\text { each other better. I now know different things about my mates thanks to this. I don't know why } \\
\text { we didn't before but we started to talk to each other in class more also" }\end{array}$ \\
\hline E1 & $\begin{array}{l}\text { "I wasn't very happy about it first but later it was different. I could catch up on what was going } \\
\text { on around more and felt like I should check more although it was still again more work" }\end{array}$ \\
\hline E4 & $\begin{array}{l}\text { "To me it was still English lesson but how can I say.. I started to be more involved in the whole } \\
\text { thing and be more open. I wish it continued more". }\end{array}$ \\
\hline
\end{tabular}

Table 14. Some of the students' responses that led way to the theme "fun"

\begin{tabular}{cl}
\hline Student & \multicolumn{1}{c}{ Response } \\
\hline K2 & $\begin{array}{l}\text { "I mean it was really different to see Facebook in the class and I have enjoyed it very much. I } \\
\text { think we all liked it anyway.. And our teacher as well" }\end{array}$ \\
\hline E3 & $\begin{array}{l}\text { "I don't know what to say .. It was like having a break while you are learning English.. and I } \\
\text { think it was a lot of fun". }\end{array}$ \\
\hline E5 & $\begin{array}{l}\text { "Well to be honest, at the beginning I wasn't really sure and I was afraid. What would my } \\
\text { friends think about my posts? And OK it was still homework and project and staff but I had a } \\
\text { lot of fun. I usually checked it with my friend (E6) and it was good, it was a laugh" }\end{array}$ \\
\hline
\end{tabular}

Table 15. Codes and Themes

\begin{tabular}{ccc}
\hline CODE & FREQUENCY & THEME \\
\hline Enabled easy communication & 10 & Communication \\
\hline More communication opportunities & 10 & \\
\hline $\begin{array}{c}\text { Sharing (posts, videos, etc.) leading to better } \\
\text { communication }\end{array}$ & 9 & Fun \\
\hline Total & 29 & \\
\hline Chance to have more enjoyable time & 9 & \\
\hline Chatting, joking about daily issues & 9 & \\
\hline Having fun outside school & 4 & \\
\hline Having more enjoyable activities & 30 \\
\hline Total
\end{tabular}

\section{DISCUSSION AND CONCLUSION}

How social media is used and what students think of these practices have been addressed by a number of scholars as aforementioned. The internet, mobile phones and social media are the complementary part of the students' environment in which they grew up and therefore today's students differ from the previous generations to a great extent in many ways such as thinking, learning and processing information. Yet, socialization and interaction features of the social media coming from its own nature can increase interaction among students which can contribute to their social presence and increase the quality of participation in learning process in a more effective learning environment. This may also be true for attitude (Lewis and Nichols, 2016). Consequently, it is usually the assumption that if students have high social presence, their attitudes toward using social media in the classroom will be more positive as well, which was the underlying idea behind this study. 
However, when looked at the findings of this study, it is interesting to note that while there was a significant increase in students' social presence after the implementation, the difference was insignificant for the students' attitude to social media. Yet, students mentioned the effects of using Facebook in EFL classes, some of which were categorized in themes as communication and fun. So what happened and how come students' social presence increased but their attitude was not affected at the end of this study? This may be attributed to several reasons including but not limited to a) students valued the content of the course enriched with social media for their education but they did not see it encouraging enough in terms of their attitude b) the fact that they knew each other for a long time and considered the social media tool only as part of the curriculum c) the fact that they used other forms of social media as well to communicate and were already comfortable with their environment. All students in this study reported use of more than one social media tool. While their standard modes of social communication with other students and instructors were through Facebook, they did not necessarily use it to socially communicate with each other or with instructors or better say they did not need an integrated social media tool in their curriculum to make them communicate more which would ultimately result in having a more positive attitude to social media.

Taking specifically, it is true that when a social media tool is introduced, it is welcomed by the majority of students and embraced readily (Albayrak \& Yildirim, 2015; Ramirez, 2017). As expected the students in this study considered Facebook as part of the curriculum, welcomed and valued it but this did not contribute to their attitude significantly. The social media tool offered outside the students' regular classroom environment was interesting and exciting in their academic realm, increased their social presence significantly but it kept its place there. Yet, it can still be argued that the advantages of using social media for educational purposes in EFL classes outweigh the disadvantages and the negative attributes can be controlled and one way of achieving this might be keeping and maintaining professionalism as well as setting boundaries and modelling appropriate use of social media. A plausible explanation might be that the students may have not felt the need for the introduction of a social media tool for non-academic connections which ultimately may have led them to remain neutral. This could also be interpreted as students had already positive attitude to social media and they did not need an extra intervention to make their attitude more positive, especially knowing that they are constantly monitored by their teachers. As some of the literature regarding this subject indicated students may have wanted to keep their privacy to themselves (Donlan, 2014; Prescott, Wilson, \& Becket, 2013; Voivonta and Avraamidou, 2018).

Despite the limited scope of current study, the results of this study indicate that students were happy to use a social media tool as part of their curriculum as it helped them have better communication with their peers in the academic realm and was enjoyable which ultimately resulted in increased social presence. The implementation for this study was designed for academic communication and the students showed high level of social presence after the implementation period and to this end, the results of this study is aligned with prior research (Akcaoglu \& Lee, 2018; Keles, 2018; Law, Geng \& Li, 2019). Why social presence is important has been revealed in many studies suggesting the use of social media tools to foster development of social presence via self-disclosure, leading to better student motivation, perceived learning and a comfortable classroom climate. Since the social presence levels of students increased significantly after the implementation, it is still possible to argue that social media tools enhance social interactions with and among students and help to form effective learning environments (Sato \& Ballinger, 2016; Tarchi \& Pinto, 2017). Consequently, integration of new technologies to current educational environments caused significant changes in learning processes as a whole and learning outcomes. Students need communication opportunities like they have in their daily lives and mention the lack of such opportunities. It is suggested that the lack of impersonal course content does not answer the needs of students even if it is applied with different methods. Whether social media is adopted in academia or not, it is possible to say that social media can enhance student learning and should not be disregarded (Lim \& Richardson, 2016; Naghdipour, 2017; Balaman \& Sert, 2017; Dung \& Ouynh, 2018).

On the whole, it is true that students who learn English as a foreign language have to struggle through different types of learning difficulties which include a lack of motivation, self-efficacy and high anxiety (Chu, Wang \& Wang, 2019; Cheng \& Chen, 2019). In this context, research about using social media for the purposes of education signify the benefits as well as the potentials of it where students can have the opportunity of sharing resources and developing communication among other skills such as making meaning 
in an authentic learning environment that would decrease the potential problems. This also underlines the importance of embedding language learning in stimulative and communicative environments which gives users a chance to gain interaction and language socialization outside the formal learning environments. (Pavlović \& Prokopović, 2015; Kesici, 2019; Muls et.al., 2019). To be more specific, it can be said that social media research is still young and more research is needed to get more insight into students' interaction in social media environments (Wirtz \& Gottel, 2016). Integrating social media that students may also use outside the classroom can be a vehicle to help the educational program to be connected to their 'real life' and generate meaningful content with which more effective educational outcomes can be achieved.

\section{Limitations}

Although the current study is thought to have provided some insights, there are a number of limitations that should be taken into consideration. First, the sample size was small, with only 32 participants in both the experimental and the control groups. There were differences that could not be included among participants such as motivation. This can be taken as a serious limitation which also restrains its generalizability to a larger population. Second, the experiment lasted for seven weeks. Conducting the study with a number of participants over a longer time period might suggest different results and can erase most of the questions that might come up regarding findings. Yet, this study took place in EFL in Turkish context and can be taken as a highlighter signifying a need to more research which would include various EFL learners with different contextual variables.

Acknowledgements: I would like to highlight that I do not have any conflict of interest with anyone and thank everyone who participated in this study.

\section{BIODATA and CONTACT ADDRESSES of AUTHOR}

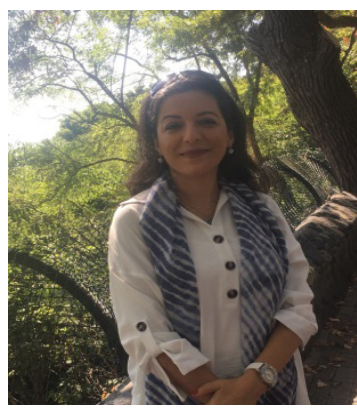

Dr. Sibel Ergun ELVERICI is currently teaching at Yildiz Technical University, School of Foreign Languages. She graduated from Marmara University, Faculty of Education, ELT Department with a first class degree. She received her M.A in Bogazici University ELT Department and conducted her PhD on Educational Technology in Bahcesehir University. After her $\mathrm{PhD}$, she started an M.A programme on Special Education in Marmara University and is now working on her thesis. Her research interests focus on technology integration, English as a Foreign Language, mobile technologies, Web 2.0,social presence and teacher education including different aspects of Special Education.

Sibel Ergun ELVERICI

School of Foreign Languages

Address: Yildiz Technical University, 34220, Istanbul, Turkey

Phone: +90 2123834920

E-mail: elverici@yildiz.edu.tr 


\section{REFERENCES}

Akbari, E., Naderi, A., Simons, R. J., \& Pilot, A. (2016). Student engagement and foreign language learning through online social networks. Asian-Pacific Journal of Second and Foreign Language Education, $1(1), 4$.

Akcaoglu, M., \& Lee, E. (2018). Using Facebook groups to support social presence in online learning. Distance Education, 39(3), 334-352.

Albayrak, D., \& Yildirim, Z. (2015). Using social networking sites for teaching and learning: Students' involvement in and acceptance of Facebook ${ }^{\circledR}$ as a course management system. Journal of Educational Computing Research, 52(2), 155-179.

Anankulladetch, Phasita, "The Impact of Social Media on ESL Students' Learning Performance” (2017). Capstone Projects and Master's Theses. 135.

Arbaugh, J. B., Cleveland-Innes, M., Diaz, S. R., Garrison, D. R., Ice, P., Richardson, J. C., \& Swan, K. P. (2008). Developing a community of inquiry instrument: Testing a measure of the community of inquiry framework using a multi-institutional sample. The internet and higher education, 11(3-4), 133-136.

Aydin, S. (2014). Foreign Language Learners' Interactions with Their Teachers on Facebook. System, 42, 155-163. DOI:10.1016/j.system.2013.12.001.

Bahati, B. (2015). Extending student discussions beyond lecture room walls via Facebook. Journal of Education and Practice, 6(15), 160-171.

Balaman, U., \& Sert, O. (2017). Development of L2 interactional resources for online collaborative task accomplishment. Computer Assisted Language Learning, 30(7), 601-630.

Chandran, Y., Plaindaren, C. J., Pavadai, S., \& Yunus, M. M. (2019). Collaborative Writing: An Integration of Snack Bars and Hi-Five Fingers via Social Media. Creative Education, 10(02), 475.

Chen, M. M. (2018). Students' perceptions of the educational usage of a Facebook group. Journal of Teaching in Travel \& Tourism, 18(4), 332-348.

Chu, H.-C., Wang, C.-C., \& Wang, L. (2019). Impacts of Concept Map-Based Collaborative Mobile Gaming on English Grammar Learning Performance and Behaviors. Educational Technology \& Society, 22 (2), 86-100.

Chugh, R., \& Ruhi, U. (2018). Social media in higher education: A literature review of Facebook. Education and Information Technologies, 23(2), 605-616.

Chugh, R., \& Joshi, M. (2017). Challenges of knowledge management amidst rapidly evolving tools of social media. In Chugh, R (ed), Harnessing Social Media as a Knowledge Management Tool, IGI Global, 299- 314, doi: 10.4018/978-1-5225-0495-5.ch014

Cox, D. \& McLeod, S. (2014). Social media strategies for school principals. NASSP Bulletin, 98 (1) (2014), pp. $5-25$

Cetinkaya, L., \& Sutcu, S. S. (2018). Students' success in English vocabulary acquisition through multimedia annotations sent via Whatsapp. Turkish Online Journal of Distance Education, 20(4), 85-98.

Dizon, G. (2016). A comparative study of Facebook vs. paper-and-pencil writing to improve L2 writing skills. Computer Assisted Language Learning, 29(8), 1249-1258.

Donlan, L. (2014). Exploring the views of students on the use of Facebook in university teaching and learning. Journal of Further and Higher Education, 38(4), 572-588.

Dung, T. N. T., \& Quynh, L. T. N. (2018). The incorporation of Facebook in language pedagogy: Merits, defects, and implications. 15th Asia TEFL and 64th TEFLIN International Conference on English Language Teaching, July 13-15, 2018, Yogyakarta, Indonesia (pp. 529-536). Routledge.

Facebook (2019). Company info: Facebook newsroom. http://newsroom.fb.com/company-info/. 
Godwin-Jones, R. (2019). In a World of SMART Technology, Why Learn Another Language? Educational Technology ひSociety, 22 (2), 4-13.

Gordon, J. (2016). How is language used to craft social presence in facebook? a case study of an undergraduate writing course. Education and Information Technologies, 21(5), 1033-1054.

Greenhow, C., \& Askari, E. (2017). Learning and teaching with social network sites: A decade of research in K-12 related education. Education and Information Technologies, 22(2), 623-645.

Greenhow, C., \& Robelia, B. (2009). Old communication, new literacies: Social network sites as social learning resources. Journal of Computer-Mediated Communication, 14(4), 1130-1161.

Greenhow, C. \& Lewin, C. (2016) Social media and education: reconceptualizing the boundaries of formal and informal learning, Learning, Media and Technology, 41:1, 6-30, DOI: $10.1080 / 17439884.2015 .1064954$

Ha, L., Joa, C. Y., Gabay, I., \& Kim, K. (2018). Does college students' social media use affect school e-mail avoidance and campus involvement?. Internet Research, 28(1), 213-231.

Hewitt, A., \& Forte, A. (2006). Crossing boundaries: Identity management and student/faculty relationships on the Facebook. Poster presented at CSCW, Banff, Alberta, 1-2.

Hong, Y., \& Gardner, L. (2019). Undergraduates' perception and engagement in Facebook learning groups. British Journal of Educational Technology.

Huang, H. Y., Wu, H. L., She, H. C., \& Lin, Y. R. (2014). Enhancing Students' NOS Views and Science Knowledge Using Facebookbased Scientific News. Journal of Educational Technology \& Society, 17(4), 289-301.

Imlawi, J., \& Gregg, D. (2014). Engagement in online social networks: The impact of self-disclosure and humor. International Journal of Human-Computer Interaction, 30(2), 106-125.

Kang, S. H., \& Gratch, J. (2014). Exploring users' social responses to computer counseling interviewers' behavior. Computers in Human Behavior, 34, 120-130.

Kawachi, P. (2019). 9. Role of Social Media in Learning: Benefits and Drawbacks—How Social Presence Theory. Social Media in Higher Education: Case Studies, Reflections and Analysis, 2.

Keles, E. (2018). Use of Facebook for the Community Services Practices course: Community of inquiry as a theoretical framework. Computers \& Education, 116, 203-224.

Kesici, A. (2019). Do Social Students Use Social Media More Often?. Turkish Online Journal of Distance Education, 20(2), 121-133.

Lantz-Andersson, A. (2018). Language play in a second language: Social media as contexts for emerging Sociopragmatic competence. Education and Information Technologies, 23(2), 705-724.

Lau, W. W. F, Lui, V. \& Chu, S.K.W. (2016). The use of wikis in a science inquiry-based project in a primary school. Educational Technology Research and Development (2016), 10.1007/s11423-0169479-9

Law, K. M., Geng, S., \& Li, T. (2019). Student enrollment, motivation and learning performance in a blended learning environment: The mediating effects of social, teaching, and cognitive presence. Computers \& Education, 136, 1-12.

Leong, L. W., Ibrahim, O., Dalvi-Esfahani, M., Shahbazi, H., \& Nilashi, M. (2018). The moderating effect of experience on the intention to adopt mobile social network sites for pedagogical purposes: An extension of the technology acceptance model. Education and Information Technologies, 23(6), 2477-2498.

Lewis, B. K., \& Nichols, C. (2016). Social Media and Strategic Communication: A Three-Year Study of Attitudes and Perceptions about Social Media among College Students. Public Relat. J, 10(1), $1-23$. 
Lim, J., \& Richardson, J. C. (2016). Exploring the effects of students' social networking experience on social presence and perceptions of using SNSs for educational purposes. The Internet and Higher Education, 29, 31-39.

Lin, V., Kang, Y. C., Liu, G. Z., \& Lin, W. (2016). Participants' experiences and interactions on Facebook group in an EFL course in Taiwan. The Asia-Pacific Education Researcher, 25(1), 99-109.

Luke, J. Y. (2019, January). Portraying the Use of Facebook for Educational Purposes Among Female Undergraduates: Causes and Activities. In UICELL Conference Proceeding (No. 2, pp. 38-44).

Ma, Q. (2017). A multi-case study of university students' language-learning experience mediated by mobile technologies: a socio-cultural perspective. computer assisted language learning, 30(3-4), 183-203.

Madge, C., Meek, J., Wellens, J., \& Hooley, T. (2009). Facebook, social integration and informal learning at university: It is more for socialising and talking to friends about work than for actually doing work'. Learning, media and technology, 34(2), 141-155.

Manca, S., \& Ranieri, M. (2016). Facebook and the others. Potentials and obstacles of social media for teaching in higher education. Computers \& Education, 95, 216-230.

Menzies, R., Petrie, K., \& Zarb, M. (2017). A case study of Facebook use: Outlining a multi-layer strategy for higher education. Education and Information Technologies, 22(1), 39-53.

Muls, J., Triquet, K., Vlieghe, J., De Backer, F., Zhu, C., \& Lombaerts, K. (2019). Facebook group dynamics: an ethnographic study of the teaching and learning potential for secondary school teachers. Learning, Media and Technology, 44(2), 162-179.

Naghdipour, B. (2017). Close Your Book and Open Your Facebook' : A Case for Extending Classroom Collaborative Activities Online. The Journal of AsiaTEFL volume 14, issue 1, P130-143 DOI: 10.18823/asiatefl.2017.14.1.9.130

Nagel, T. W., Remillard, C., Aucoin, R., \& Takenishi, A. (2018). Findings on Student Use of Social Media at the Collegiate, Undergraduate, and Graduate Levels: Implications for Post-Secondary Educators. Journal of University Teaching \& Learning Practice, 15(1), 8.

Nalbone, D. P., Kovach, R. J., Fish, J. N., McCoy, K. M., Jones, K. E., \& Wright, H. R. (2016). Social networking web sites as a tool for student transitions: Purposive use of social networking web sites for the first-year experience. Journal of College Student Retention: Research, Theory \& Practice, 17(4), 489-512.

Oh, C. S., Bailenson, J. N., \& Welch, G. F. (2018). A systematic review of social presence: definition, antecedents, and implications. Front. Robot. AI 5: 114. doi: 10.3389/frobt.

Otrar, M., \& Argin, F. S. (2015). Ogrencilerin sosyal medyaya iliskin tutumlarini belirlemeye yonelik bir olcek gelistirme calismasi. Egitim ve Ogretim Arastirmalari Dergisi, 4(1), 391-403.

Patton, M. Q. (2002). Two decades of developments in qualitative inquiry: A personal, experiential perspective. Qualitative social work, 1(3), 261-283.

Pavlović D., Mihajlov Prokopović A. (2015). Attitudes of teachers to the application of computers in preschools. In The 11th International Scientific Conference eLearning and software for Education Bucharest, Carol I NDU Publishing House, Vol 1, (277-283), Page 278-279.

Peeters, W. (2018) Applying the networking power of Web 2.0 to the foreign language classroom: a taxonomy of the online peer interaction process, Computer Assisted Language Learning, 31:8, 905-931, DOI: $10.1080 / 09588221.2018 .1465982$

Prescott, J., Wilson, S., \& Becket, G. (2013). Facebook use in the learning environment: do students want this? Learning, Media and Technology, 38(3), 345-350.

Ramirez, D. M. (2017). Attitudes of Students and Faculty Toward Using Computer Technology and Twitter for Online Learning and Student Engagement: A Cross-Sectional Analysis. PhD Dissertation. St. Thomas University. 
Rap, S., \& Blonder, R. (2016). Let's face (book) it: Analyzing interactions in social network groups for chemistry learning. Journal of Science Education and Technology, 25(1), 62-76.

Sato, M., \& Ballinger, S. (Eds.). (2016). Peer interaction and second language learning: Pedagogical potential and research agenda (Vol. 45). John Benjamins Publishing Company.

Sheeran, N., \& Cummings, D. J. (2018). An examination of the relationship between Facebook groups attached to university courses and student engagement. Higher Education, 76(6), 937-955.

Short, J., Williams, E., \& Christie, B. (1976). The social psychology of telecommunications. John Wiley \& Sons.

Sung, E., \& Mayer, R. E. (2012). Five facets of social presence in online distance education. Computers in Human Behavior, 28(5), 1738-1747.

Suswati, R., \& Saleh, S. (2019). The Use of Social Media in Designing The Writing Assessment for EFL Students. Journal of ELT Research, 26-34.

Tarchi, C., \& Pinto, G. (2016). Reciprocal teaching: Analyzing interactive dynamics in the co-construction of a text's meaning. The Journal of Educational Research, 109(5), 518-530.

Voivonta, T., \& Avraamidou, L. (2018). Facebook: a potentially valuable educational tool?. Educational Media International, 55(1), 34-48.

Ware, P., Kern, R., \& Warschauer, M. (2016). 14 The development of digital literacies. Handbook of second and foreign language writing, 11, 307.

Wei, C., Chen, N., \& Kinshuk. (2012). A model for social presence in online classrooms. Education Technology Research and Development, 60 (3), 529-545.

Williams, E. (1978a). Teleconferencing: Social and psychological factors. Journal of Communication, 84, $125-131$.

Wirtz, B. W., \& Gottel, V. (2016). Technology acceptance in social media: review, synthesis and directions for future empirical research. Journal of Electronic Commerce Research, 17(2), 97.

Wood, J. (2014). College Students In Study Spend 8 to 10 Hours Daily on Cell Phone. Psych Central. https://psychcentral.com/news/2014/08/31/new-study-finds-cell-phone-addiction-increasinglyrealistic-possibility/74312.html

Zhang, Z., \& Gupta, B. B. (2018). Social media security and trustworthiness: overview and new direction. Future Generation Computer Systems, 86, 914-925.

Zheng, B., Yim, S., \& Warschauer, M. (2018). Social media in the writing classroom and beyond. The TESOL Encyclopedia of English Language Teaching, 1-5.

Zincir, O. (2017). Knowledge workers' social media usage as a personal knowledge management tool. In Harnessing Social Media as a Knowledge Management Tool (pp. 108-124). IGI Global. 